University of Nebraska - Lincoln

DigitalCommons@University of Nebraska - Lincoln

Faculty Publications from the Harold W. Manter Laboratory of Parasitology

2001

\title{
Onchocercosis in Red Deer (Cervus elaphus) from Spain
}

\author{
Mónica Santín-Durán \\ Universidad Complutense \\ José M. Alunda \\ Universidad Complutense \\ Eric P. Hoberg \\ United States Department of Agriculture, Agricultural Research Service, geocolonizer@gmail.com
}

Follow this and additional works at: https://digitalcommons.unl.edu/parasitologyfacpubs

Part of the Biodiversity Commons, Parasitology Commons, and the Zoology Commons

Santín-Durán, Mónica; Alunda, José M.; and Hoberg, Eric P., "Onchocercosis in Red Deer (Cervus elaphus) from Spain" (2001). Faculty Publications from the Harold W. Manter Laboratory of Parasitology. 659. https://digitalcommons.unl.edu/parasitologyfacpubs/659

This Article is brought to you for free and open access by the Parasitology, Harold W. Manter Laboratory of at DigitalCommons@University of Nebraska - Lincoln. It has been accepted for inclusion in Faculty Publications from the Harold W. Manter Laboratory of Parasitology by an authorized administrator of DigitalCommons@University of Nebraska - Lincoln. 


\section{Onchocercosis in Red Deer (Cervus elaphus) From Spain}

Mónica Santín-Durán, José M. Alunda, Concepción de la Fuente*, and Eric P. Hoberg†, Departamento de Patología Animal I (Sanidad Animal), Facultad de Veterinaria, Universidad Complutense, 28040 Madrid, Spain. * To whom correspondence should be addressed. $†$ Biosystematics and National Parasite Collection Unit, USDA, ARS, BARC-East, Building 1180, Beltsville, Maryland 20705. email: msantin@eucmax.sim.ucm.es

ABSTRACT: Onchocercosis, caused by Onchocerca flexuosa, was observed in red deer (Cervus elaphus) from Spain for the first time. Adult specimens of $O$. flexuosa were found in nodules in subcutaneous tissues in 42 of $125(33 \%)$ red deer between October 1994 and September 1995 ; intensity of infection \pm SD was $3.93 \pm 5.26$ nodules per infected host. A clear seasonal pattern in the distribution of nodules was observed, with higher values of prevalence and intensity in fall and winter in contrast to spring and summer. Significant differences were found among age groups in prevalence, but not in the mean intensity. No differences in infection were apparent between male and female adult red deer.

Onchocercosis was reported for the first time in cattle by Stiles in 1892 and subsequently in other domestic and wild ruminants. Most of the records for onchocercosis in wild ruminants have been limited to eastern Europe, and based on these reports, Onchocerca spp. may have 
TABLE I. Prevalence and mean intensity of nodules of $O$. flexuosa in red deer from Spain.*

\begin{tabular}{|c|c|c|c|c|c|c|}
\hline Prevalence & 33.6 & 3.45 & 19.05 & 49.33 & 51.43 & 47.5 \\
\hline $\mathrm{n}$ & 125 & 29 & 21 & 75 & 35 & 40 \\
\hline
\end{tabular}

* n, number of animals; prevalence, percentage of deer infected; mean intensity, number of nodules per deer infected.

TABLE II. Seasonal prevalence and mean intensity of $O$. flexuosa in red deer from Spain.*

\begin{tabular}{lcccc}
\hline & & & Season & \\
\cline { 2 - 5 } & Fall & Winter & Spring & 14.81 \\
\hline Prevalence & 45.95 & 42.42 & 25 & Summer \\
Mean intensity \pm SD & $5.47 \pm 7.19$ & $3.71 \pm 3.49$ & $1.57 \pm 0.73$ & $2.25 \pm 2.16$ \\
$\mathrm{n}$ & 37 & 33 & 28 & 27 \\
\hline
\end{tabular}

* n, number of animals; prevalence, percentage of deer infected; mean intensity, number of nodules per deer infected.

restricted distributions in Poland (Dróżdż, 1966; Demiaszkiewicz and Dróżdż, 1990; Demiaszkiewicz, 1993, 1995; Dróżdż et al., 1993, 1994), Germany (Schulz-Key, 1975; Franz et al., 1987), the Czech Republic, and the Slovak Republic (Baruš, 1994). However, this may be simply a reflection of the geographic localities where studies have been conducted.

Five species of Onchocercinae have been reported in red deer (Cervus elaphus L.) from Poland, including O. flexuosa, O. jakutensis, O. garmsi, O. skrjabini, and Cutifilaria wenki (Demiaszkiewicz, 1995). Among these, $O$. flexuosa is more frequently found in nodules from subcutaneous tissue in red deer, which appear to be a primary host for this filariid. In addition, Onchocerca flexuosa has been found in roe deer (Capreolus capreolus L.), particularly in areas of sympatry with $C$. elaphus (Demiaszkiewicz and Dróżdż, 1990). The former cervid appears to be an atypical host for this species because $O$. flexuosa was found in 1 of 209 roe deer examined in Poland (Demiaszkiewicz and Dróżdż, 1990).

In the present study, new findings on the distribution of $O$. flexuosa in red deer are reported from Spain. The survey was undertaken in Quintos de Mora, a government-owned and managed park located near Toledo $\left(39^{\circ} 25^{\prime} \mathrm{N}, 4^{\circ} 4^{\prime} \mathrm{W}\right)$. The 6,864-ha park is composed of 2 different habitats, including a plateau at $800 \mathrm{~m}$ above sea level, crossed by the Las Navas River, and a mountainous area reaching 1,235 $\mathrm{m}$ in elevation. The survey for parasites extended over a 1-yr period and involved monthly collections from October 1994 to September 1995 (at least 9 red deer/mo when possible). Fall, winter, spring, and summer refer, respectively, to the periods October-December, January-March, AprilJune, and July-September. One hundred and twenty-five red deer were divided into 3 age groups: fawns $<1$ yr old (29), yearlings $1-2 \mathrm{yr}$ old (21), and adults $>2 \mathrm{yr}$ old (75); the latter included 35 males and 40 females. At necropsy, the skin was removed from each animal and examined for subcutaneous nodules. All nodules were collected and fixed in phosphate-buffered formalin $(5 \%)$. Adult filarial nematodes recovered from the nodules were studied as temporary whole mounts cleared in phenol-alcohol ( 80 parts melted phenol crystals and 20 parts absolute ethanol) and examined with light microscopy using differential interference contrast optics. Statistical analysis was performed at the Universidad Complutense, Madrid, Computer Center using BMDP Statistical Software (Dixon, 1993) and included parametric (Fisher's test, Student's $t$-test, and Tukey test) and chi-square nonparametric tests. Statistical significance was determined at the $P \leq 0.05$ level.

Nematodes recovered from nodules in red deer from Quintos de Mora were identified as $O$. flexuosa, which represents a new geographic record from Spain. Because of the difficulty of recovering and accurately counting entire worms, only some specimens were identified; prevalence and mean intensity reported below are thus based on data for nodules. Representative specimens are deposited in the U.S. National Parasite Collection (USDA, Agricultural Research Service, Beltsville, Maryland; USNPC nos. 90682-90684), and in the Parasite Collection of the Departamento de Patología Animal I (Universidad Complutense de Madrid, Madrid, Spain).

Nodules were recovered from 42 of 125 (33\%) red deer. Overall, mean intensity ( $\pm \mathrm{SD}$ ) was $3.93 \pm 5.26$ (range 1 to 20 ) nodules per infected host. The highest prevalence was found in adult red deer $(49 \%)$, followed by yearlings (19\%) and fawns (3\%) (Table I). Differences in prevalence among age categories were significant $(P<0.0001)$, but no significant differences between males and females were observed. The higher prevalence in adults than in fawns could be related to the limited time of contact with intermediate hosts for young animals because birth takes place in May-June. With respect to intensity, no differences were observed based on age and sex of hosts. Significant variation in prevalence was observed among seasons $(P<0.0001)$, with higher values in fall and winter than in spring and summer (Table II). Variation in mean intensity was also seasonally defined, with the highest values in fall (5.47 \pm 7.19 nodules/host, $P=0.0029$; Table II).

Direct comparison of our results and those from other regions and previous studies is complex. The influence of differing latitudes, which determines the onset of seasonal weather patterns and, thus, the activity of vectors, may affect comparisons. Additionally, these data have been based on nodules that contain adult nematodes, whereas prevalence in other studies has generally been based on the presence of microfilariae in skin (Dróżdż et al., 1993). Irrespective of these factors, the prevalence of $O$. flexuosa in red deer was variable in different regions of Poland, ranging from 14.2 to $80.3 \%$ (Demiaszkiewicz, 1995), and in Germany, 96\% (Schulz-Key, 1975). Such values often exceeded those observed in red deer from Spain.

At Quintos de Mora, adults of $O$. flexuosa are present in subcutaneous tissues between October and March, with prevalence and intensity decreasing subsequently in spring and summer. An apparent decrease in the presence of adults may coincide with increasing microfilaraemia and with seasonal periods of activity for simulid or ceratopogonid intermediate hosts. This observation is in agreement with the results obtained by Dróżdż et al. (1993), who observed a peak of microfilariae of Onchocerca spp. in red deer during May. Consequently, patterns of distribution and seasonality for Onchocerca appear linked to those of intermediate hosts such that the potential for transmission may be maximal.

We are sincerely grateful for the financial support by ICONA (Project B-44/1994). Mónica Santín Durán was covered by a predoctoral fellowship from Comunidad de Madrid. The cooperation of José Manuel Sebastián, Carlos Rodríguez Vidal, and José María San Miguel Ayanz was critical. Warden services helped us in the sampling. 


\section{LITERATURE CITED}

BARUŠ, V. 1994. Revised checklist of filariids parasitizing in red deer species (Cervidae) in the Czech Republic and the Slovak Republic. Folia Venatoria 24: 69-75.

DemiasZKIEWICZ, A. W. 1993. Redescription of Onchocerca jakutensis (Gubanov, 1964) (Nematoda, Filaroidea). Acta Parasitologica 38: 124-127.

1995. Studies on tissue nematodes from subfamily Onchocercinae Leiper, 1911 in free living and domestic ruminants in Poland. Warsaw Agricultural University Press, Warsaw, Poland, 104 p.

-, AND J. DRóżDż. 1990. The roe deer, Capreolus capreolus (L.) as a new host of Onchocerca flexuosa (Wedl, 1856) (Nematoda, Filarioidea). Acta Parasitologica Polonica 35: 315-318.

DixON, W. J. 1993. BMDP statistical software manual. University of California Press, Berkeley, California, 1500 p.
DRÓżDż, J. 1966. Studies on helminths and helminthiases in Cervidae II. The helminth fauna in Cervidae in Poland. Acta Parasitologica Polonica 14: 1-13.

, A. W. Demiaszkiewicz, and J. Lachowicz. 1993. Seasonal changes in the helminth fauna of Cervus elaphus (L.) from Slowinski National Park (Poland). Acta Parasitologica 38: 85-87.

- -1994 . The effect of culling red deer, Cervus elaphus (L.), on their helminth fauna in the Slowinski National Park (Poland). Acta Parasitologica 39: 92-94.

Franz, M., H. Schulz-Key, and D. B. Copeman. 1987. Electron-microscopic observations on the female worms of six Onchocerca species from cattle and red deer. Parasitology Research 74: 73-83.

SchulZ-Key, H. 1975. Studies on the filariidae of roe deer, fallow deer and red deer in Southern Germany. In Proceedings of Second European Multicolloquium of Parasitology, Trogir, Croatia, p. 329333. 